\title{
Correction to: Identification and functional analysis of a three-miRNA ceRNA network in hypertrophic scars
}

Zewei Zhang ${ }^{1,2+} \mathbb{D}^{\circ}$, Xin Huang ${ }^{2 \dagger}$, Jiahao Yang ${ }^{3 \dagger}$, Shuchen $\mathrm{Gu}^{2}$, Yixuan Zhao ${ }^{2}$, Yunhan Liu ${ }^{2}$, Yimin Khoong ${ }^{2}$, Shuqi Wang ${ }^{1}$, Shenying Luo ${ }^{2}$, Tao Zan ${ }^{2 *}$ and Guangshuai Li ${ }^{1^{*}}$

\section{Correction to: J Transl Med (2021) 19:451} https://doi.org/10.1186/s12967-021-03091-y

In the original publication [1], there was an incorrect funding section. The incorrect and correct funding information is published in this correction article. The original article has been updated.

\section{Incorrect funding}

This work was supported by the National Natural Science Foundation of China (Grant Number: 81873538) and Key Scientific Research Projects of Colleges and Universities in Henan Province (Grant Number: 20A320033).

\section{Correct funding}

This work was supported by the National Natural Science Foundation of China (Grant Number: 81772086, 82072177) and Key Scientific Research Projects of Colleges and Universities in Henan Province (Grant Number: 20A320033).

\begin{abstract}
Author details
${ }^{1}$ Department of Plastic and Reconstructive Surgery, The First Affiliated Hospital of Zhengzhou University, Zhengzhou, China. ${ }^{2}$ Department of Plastic and Reconstructive Surgery, Shanghai Ninth People's Hospital, Shanghai Jiaotong University School of Medicine, Shanghai, China. ${ }^{3}$ Department of Orthopedic, The First Affiliated Hospital of Zhengzhou University, Zhengzhou, China.
\end{abstract}

Published online: 18 January 2022

Reference

1. Zhang Z, Huang $X$, Yang J, Gu S, Zhao Y, Liu Y, Khoong Y, Wang S, Luo S, Zan T, Li G. Identification and functional analysis of a three-miRNA ceRNA network in hypertrophic scars. J Transl Med. 2021;19:451. https://doi.org/ 10.1186/s12967-021-03091-y.

\section{Publisher's Note}

Springer Nature remains neutral with regard to jurisdictional claims in published maps and institutional affiliations.

${ }^{1}$ Department of Plastic and Reconstructive Surgery, The First Affiliated

Full list of author information is available at the end of the article original author(s) and the source, provide a link to the Creative Commons licence, and indicate if changes were made. The images or other third party material in this article are included in the article's Creative Commons licence, unless indicated otherwise in a credit line to the material. If material is not included in the article's Creative Commons licence and your intended use is not permitted by statutory regulation or exceeds the permitted use, you will need to obtain permission directly from the copyright holder. To view a copy of this licence, visit http://creativecommons.org/licenses/by/4.0/. The Creative Commons Public Domain Dedication waiver (http://creativecommons.org/publicdomain/zero/1.0/) applies to the data made available in this article, unless otherwise stated in a credit line to the data. 